\title{
An Effectiveness of Oral Health Promotion Program on 12 Year old School Going Children of South Indian Children
}

\author{
Poornima P. 1, Sathyaki Arora ${ }^{2}$, Neena IE ${ }^{3}$ \\ Shashibhushan KK ${ }^{4}$, Nagaveni NB ${ }^{5}$
}

Professor \& Head ${ }^{1}$, PG Student ${ }^{2}$, Reader $^{3}$, Professor $^{4-5}$

Department of Pedodontics \& Preventive Dentistry, College of Dental Sciences, Davangere

\begin{abstract}
:
Background and Objectives: Dental care is the most common unmet health care need of children in India. The study was undertaken to test lecture method for providing oral health education to 12 year old school going children. Methods: A sample size of 200 was selected randomly from 6 different schools of Davangere district. Students who were of chronological age of 12 year from the selected schools were included in the study. Before giving lecture aid, the study group IS assessed about their self-implemented oral hygiene practices through questionnaire. The study groups were assessed immediately and 6 months after given lecture aid through a questionnaire which was designed to evaluate the knowledge, attitude, and practices of 12 year old school children regarding their oral health. The data thus collected was tabulated, assessed and statistically analyzed using student paired T-test and McNemar test. Results: There was statistically significant $(\mathrm{P}<0.001)$ improvement in the knowledge and behavior regarding oral health amongst study group with the overall improvement in correct answers. There was a significant reduction $(\mathrm{P}<0.001)$ in the memory among the study group after 6 months of oral hygiene instruction. Interpretation and Conclusion: The lecture method was effective in improving oral hygiene attitudes and skills. After 6 months, there was a significant reduction in memory gained after interventional program which dictates the need for regular reinforcement of educational and motivational programs.
\end{abstract}

Keywords: Children, Dental Caries, Oral Health, Plaque

\section{Introduction}

Oral disease constitutes one of the most prevalent chronic diseases amongst Indian children. The developing economy, lack of qualified dental manpower, poor awareness towards oral health, lack of required infrastructure and lack of political will are some possible reasons which have contributed to this picture. Many of the oral diseases and conditions affecting children are almost entirely preventable. Programs to educate and promote preventive measures have been shown to increase knowledge and also the ability to recall information related to oral health and general health ${ }^{1}$. Various models and programs to educate and promote preventive measures were undertaken ${ }^{2}$.

The lecture can be provided to different age groups in schools to increase awareness regarding oral heath, behaviour and attitude towards oral hygiene practices. Lecture can be provided using black board present in the

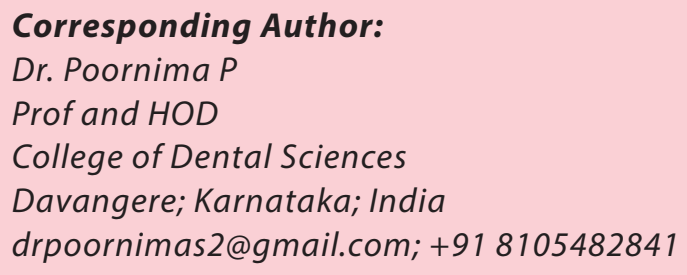

school premises to educate school going children. To provide effective lecture to school going children needs well trained person who can effectively provide education for maintaining their attention span. It is possible to increase oral-health-related knowledge following a simple teaching program. ${ }^{3}$

\section{SUBJECTS AND METHOD:}

This was a longitudinal study. The study area was Davanagre, a district in Karnataka State. There are totally 2191 primary and higher primary schools in Davangere city according to the list obtained from block education officer. Six higher primary schools were randomly selected on convenience basis, consisting of both private and public schools. An estimated sample size of 200 was selected randomly from 6 different schools of Davangere district. All children who were chronological age of 12 year from the selected schools were included in the study.

\section{Questionnaire:}

Self-designed questionnaire was prepared to collect the information pertaining to the study. The questionnaire was tested initially among 30 school children and these students were not included in the main study 
It was srtuctured in such a way as to assess child awareness, behavior, knowledge and their self-implemented oral hygiene practices. The questionnaire was also translated to the local language (Kannada) and was tested for its validity. The questionnaire consiststed of 16 key questions covering the basic information to test the knowledge, attitude and practices before and after giving lecture (Appendix 1).

\section{Method of collecting data}

All the study population was assessed about their self-implemented oral hygiene practices through questionnaire which was designed to evaluate the knowledge, attitude, and practices of 12 year old school going children regarding their oral health and dental treatment. The data was collected at three different intervals, first before the lecture, second immediately after the lecture and the third after 6 months from the study population.

The data was analysed using SPSS version 17 . The effectiveness of lecture method to increase knowledge and change in behavior \& attitude were analysed by student paired T-test and McNemar test.

\section{Results}

The responses concerning boys and girls were combined as no substantial differences in knowledge, attitude or behavior were found. The questionnaire results were evaluated on an individual basis and summarized for the whole group to check the effectiveness of the educational material presented in the lecture (Table-1, Graph-1).

Answers provided before the lecture revealed a lack of knowledge about oral health, as evidenced by the proportion of incorrect $(21.25 \%)$ responses. Significant improvement [11.7(71.8\%) SD 3.5; $\mathrm{p}<0.001]$ in the knowledge was achieved by the proportion of correct responses following lecture demonstration regarding oral health and oral hygiene (Graph-1). Graph-2 and Table-2 represents the reduction in the memory by comparing the scores of the questionnaire immediately after giving lecture and 6 months from it.
Table No. 1 :

Analysis of individual questions before and after giving lecture.

\begin{tabular}{|c|c|c|c|c|}
\hline \multirow[t]{2}{*}{ Lecture Method } & \multicolumn{2}{|c|}{$\begin{array}{l}\text { Percentage of } \\
\text { correct answers }\end{array}$} & \multirow{2}{*}{$\begin{array}{c}\text { Improvement } \\
\text { (After - Before) } \\
(\%)\end{array}$} & \multirow[t]{2}{*}{$\begin{array}{l}\text { P* Value, } \\
\text { Sig. }\end{array}$} \\
\hline & $\begin{array}{c}\text { Before } \\
(\%)\end{array}$ & $\begin{array}{l}\text { After } \\
(\%)\end{array}$ & & \\
\hline What tooth is made up of? & 15.5 & 80 & 64.5 & $\mathrm{P}<0.001 \mathrm{HS}$ \\
\hline What is plaque? & 0 & 62 & 62 & $\mathrm{P}<0.001 \mathrm{HS}$ \\
\hline What is dental caries? & 25 & 78 & 53 & $\mathrm{P}<0.001 \mathrm{HS}$ \\
\hline $\begin{array}{l}\text { What type of food causes tooth } \\
\text { decay? }\end{array}$ & 68 & 93.5 & 25.5 & $\mathrm{P}<0.001 \mathrm{HS}$ \\
\hline $\begin{array}{l}\text { What you should do to prevent } \\
\text { tooth decay? }\end{array}$ & 2.5 & 33 & 30.5 & $\mathrm{P}<0.001 \mathrm{HS}$ \\
\hline How you should clean your teeth? & 62.5 & 86 & 23.5 & $\mathrm{P}<0.001 \mathrm{HS}$ \\
\hline $\begin{array}{l}\text { How many times you should brush } \\
\text { your teeth? }\end{array}$ & 43 & 84.5 & 41.5 & $\mathrm{P}<0.001 \mathrm{HS}$ \\
\hline $\begin{array}{l}\text { How long you should brush your } \\
\text { teeth? }\end{array}$ & 5.5 & 62 & 56.5 & $\mathrm{P}<0.001 \mathrm{HS}$ \\
\hline $\begin{array}{l}\text { Is it important to clean in between } \\
\text { tooth surfaces? }\end{array}$ & 11.5 & 65.5 & 54 & $\mathrm{P}<0.001 \mathrm{HS}$ \\
\hline $\begin{array}{l}\text { What you should use to clean in } \\
\text { between tooth surfaces? }\end{array}$ & 2.5 & 66 & 63.5 & $\mathrm{P}<0.001 \mathrm{HS}$ \\
\hline Should we snack in between meals? & 22 & 73 & 51 & $\mathrm{P}<0.001 \mathrm{HS}$ \\
\hline $\begin{array}{l}\text { How many times you eat toffee, } \\
\text { candy, chocolates per day? }\end{array}$ & 12.5 & 80.5 & 68 & $\mathrm{P}<0.001 \mathrm{HS}$ \\
\hline Fluoride prevents tooth decay? & 20 & 74 & 54 & $\mathrm{P}<0.001 \mathrm{HS}$ \\
\hline $\begin{array}{l}\text { When you should visit dental } \\
\text { doctor? }\end{array}$ & 26.5 & 85.5 & 59 & $\mathrm{P}<0.001 \mathrm{HS}$ \\
\hline $\begin{array}{l}\text { What are the effects of abnormal } \\
\text { oral habits on teeth? }\end{array}$ & 18 & 74.5 & 56.5 & $\mathrm{P}<0.001 \mathrm{HS}$ \\
\hline $\begin{array}{l}\text { What is the effect of coke, Pepsi and } \\
\text { cold drinks on teeth? }\end{array}$ & 9 & 79 & 70 & $\mathrm{P}<0.001 \mathrm{HS}$ \\
\hline
\end{tabular}

GRAPH-1

Comparison of correct answers before, just after and after six months of lecture group

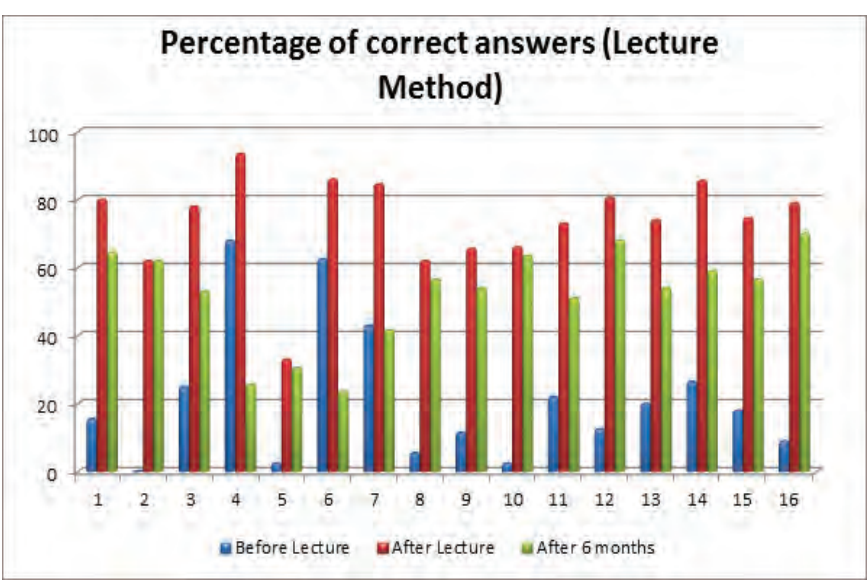


Table No. 2:

Analysis of individual questions for retention in lecture group after six months

\begin{tabular}{|l|c|c|c|c|}
\hline \multicolumn{1}{|c|}{ Lecture Method } & \multicolumn{2}{|c|}{$\begin{array}{c}\text { Percentage of } \\
\text { correct answers }\end{array}$} & $\begin{array}{c}\text { Improvement } \\
\text { (After 6 months } \\
\text { - Before) (\%) }\end{array}$ & $\begin{array}{c}\text { P* Value, } \\
\text { Sig. }\end{array}$ \\
\cline { 2 - 5 } & $\begin{array}{c}\text { Before } \\
\text { (\%) }\end{array}$ & $\begin{array}{c}\text { After } \\
\text { (\%) }\end{array}$ & & \\
\hline What tooth is made up of? & 15.5 & 51 & 35.5 & $\mathrm{P}<0.001 \mathrm{HS}$ \\
\hline What is plaque? & 0 & 36 & 36 & $\mathrm{P}<0.001 \mathrm{HS}$ \\
\hline What is dental caries? & 25 & 60.5 & 35.5 & $\mathrm{P}<0.001 \mathrm{HS}$ \\
\hline $\begin{array}{l}\text { What type of food causes tooth } \\
\text { decay? }\end{array}$ & 68 & 73 & 5 & $\mathrm{P}<0.001 \mathrm{HS}$ \\
\hline $\begin{array}{l}\text { What you should do to prevent } \\
\text { tooth decay? }\end{array}$ & 2.5 & 30.5 & 28 & $\mathrm{P}<0.001 \mathrm{HS}$ \\
\hline How you should clean your teeth? & 62.5 & 78 & 15.5 & $\mathrm{P}<0.001 \mathrm{HS}$ \\
\hline $\begin{array}{l}\text { How many times you should brush } \\
\text { your teeth? }\end{array}$ & 43 & 69.5 & 26.5 & $\mathrm{P}<0.001 \mathrm{HS}$ \\
\hline $\begin{array}{l}\text { How long you should brush your } \\
\text { teeth? }\end{array}$ & 5.5 & 44.5 & 39 & $\mathrm{P}<0.001 \mathrm{HS}$ \\
\hline $\begin{array}{l}\text { Is it important to clean in between } \\
\text { tooth surfaces? }\end{array}$ & 11.5 & 52 & 40.5 & $\mathrm{P}<0.001 \mathrm{HS}$ \\
\hline $\begin{array}{l}\text { What you should use to clean in } \\
\text { between tooth surfaces? }\end{array}$ & 2.5 & 46 & 43.5 & $\mathrm{P}<0.001 \mathrm{HS}$ \\
\hline Should we snack in between meals? & 22 & 65 & 43 & $\mathrm{P}<0.001 \mathrm{HS}$ \\
\hline $\begin{array}{l}\text { How many times you eat toffee, } \\
\text { candy, chocolates per day? }\end{array}$ & 12.5 & 56 & 43.5 & $\mathrm{P}<0.001 \mathrm{HS}$ \\
\hline Fluoride prevents tooth decay? & 20 & 70 & 50 & $\mathrm{P}<0.001 \mathrm{HS}$ \\
\hline $\begin{array}{l}\text { When you should visit dental } \\
\text { doctor? }\end{array}$ & 26.5 & 70 & 43.5 & $\mathrm{P}<0.001 \mathrm{HS}$ \\
\hline $\begin{array}{l}\text { What are the effects of abnormal } \\
\text { oral habits on teeth? }\end{array}$ & 18 & 63 & 45 & $\mathrm{P}<0.001 \mathrm{HS}$ \\
\hline $\begin{array}{l}\text { What is the effect of coke, pepsi } \\
\text { and cold drinks on teeth? }\end{array}$ & 9 & 52 & 43 & $\mathrm{P}<0.001 \mathrm{HS}$ \\
\hline
\end{tabular}

GRAPH-2

Comparison of total scores of lecture group before, just after and after six months

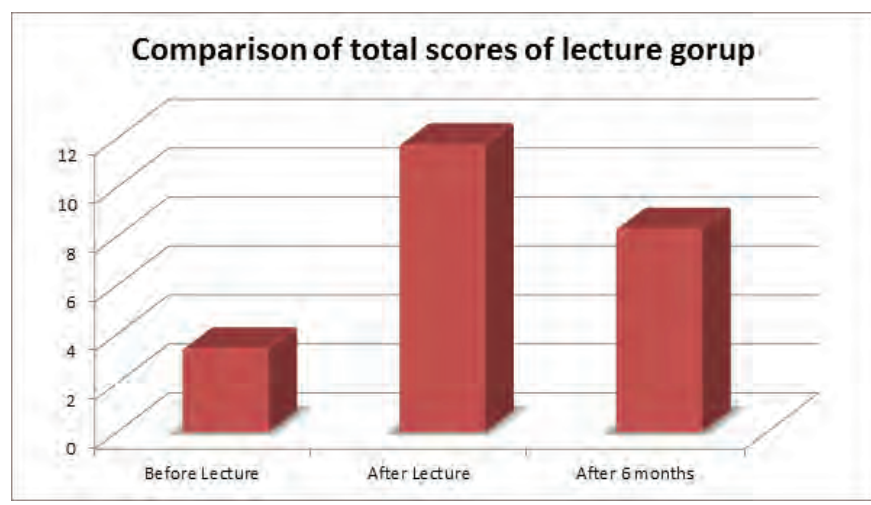

\section{Discussion:}

Dental caries is the most common chronic disease on the planet, according to the FDI, despite being preventable and with known etiology. ${ }^{4}$ The etiology and pathogenesis of dental caries are known to be multifactorial. Numerous host, agent and environmental factors play a role in the development of dental caries. ${ }^{5}$ Extensive research of last several decades has shown the crucial role played by dental plaque in the initiation and progression of dental caries.

As children spend much time in school, teachers can assist with dental health education programs. These programs have proven successful in improving knowledge and motivating oral hygiene practices via activities such as group participation, coloring/activity books, films, and interactive computer programs, parent-child information nights, contracting and rewarding behavioral changes. Behavior modeling by authority figures in a child's life such as a teacher, dentist, auxiliary or sibling can be a powerful tool. ${ }^{6}$

A Chapman, SJ Copestake and K. Duncan12-3(2006) evaluated the efficacy of a teaching program based on the national curriculum for use in a primary school setting. There was a significant increase in knowledge after teaching had taken place $(\mathrm{P}<0.001)$. After the 7-weeks gap and at the administration of the third questionnaire, there was no significant decrease in knowledge $(\mathrm{P}=0.215)$ whereas in the present study there was a significant reduction $(\mathrm{P}<0.001)$ in knowledge after 6 months. The reason may be because the duration of evaluation in the present study was longer compared to chapman study which was evaluated only 7-weeks after teaching program.

Although Albandar et $\mathrm{al}^{7}$ in his study with teenagers had found that even with the introduction of an educative program it was not possible to change the habits of those who did not take care of themselves, present study showed significant improvement, probably this occurred because of the better motivation of students through instruction program.

Previous studies involving Jordanian children by Mahmoud K. Al-Omari et al (2006) showed only $15 \%$ of the study population knew the significance of dental plaque, while the rest either did not know or reported wrong answers. ${ }^{8}$ In the present study, none of the subjects answered this question. This difference may be attributed to the lack of knowledge regarding oral health amongst school children in India or wide range of age group taken in the former study (10-16 years).

At the age of 11- 13 years most of the permanent teeth are erupted in the oral cavity and many of the teeth are still undergoing post eruptive maturation and hence are susceptible to dental caries. In a study by Mahmoud K. Al-Omari et al $76.8 \%$ of the study population knew the effect of caries in contrast to our study in which only $25 \%$ of the study population had the knowledge of caries before the intervention. ${ }^{8}$ 


\section{Knowledge and behavior about the association of diet} and dental caries:

In the present study also $68 \%$ of students were aware of the fact that sweet food causes tooth decay. In contrast to this Ernesto Smyth ${ }^{9}$ showed higher percentage 90\% of awareness. Although various factors directly or indirectly affect the variables that are under study, diet appears to be one of the major factors that can have a profound influence on the variables. Many investigators have reported a strong and significant association between the presence of dental erosion and the increased consumption of acidic drinks. The overall erosion prevalence observed by I.A. El Karim et al was $66.9 \%$ of which $45.2 \%$ was mild and $21.7 \%$ was moderate erosion. A strong association was found between erosion and private schooling (higher socioeconomic groups), carbonated drinks, herbal hibiscus drink and traditional acidic food consumption. ${ }^{10}$

\section{Knowledge and behavior regarding oral hygiene habits:}

A study in 12 year old Thai children by Poul Erik Peterson and Niels Hoerup (2001), 97\% of children agreed that brushing can prevent tooth decay, only $2 \%$ disagree as compared to present study in which $70 \%$ agree with the fact that brushing can prevent tooth decay but only $3 \%$ were able to answer that brushing, routine dental check-up and avoiding soft sticky food together will reduce the occurrence of dental canes. ${ }^{11}$

The effectiveness of brushing twice daily with toothpaste on caries is supported by data on reported behavior obtained from surveys and clinical trials. For example, among children aged $3.5-4.5$ years, $24 \%$ of those whose teeth were brushed more than once a day had caries experience compared with $38 \%$ of those whose teeth were brushed once a day and almost half (48\%) of those whose teeth were brushed less often. ${ }^{12}$ Since twice daily brushing is considered most effective, our subjects were instructed to brush two times a day after breakfast and before going to bed. ${ }^{13}$

Bin Peng et $\mathrm{al}^{14}$ showed that $40 \%$ of 12 year school going children knew the need of tooth brushing twice daily to maintain oral health similar to the present study in which $43 \%$ of children knew the need of tooth brushing at least twice a day.

Study by Gallagher et $\mathrm{al}^{15}$ evaluated the effect of brushing times and dentifrice on plaque removal concluded that oral health care professionals should reinforce efforts to persuade patients to brush for longer periods of time, as increasing brushing time to the consensus minimum of two minutes increases plaque removal and effectiveness of dentifrices to an extent likely to provide clinically significant oral health benefits. Since the time of tooth brushing is also an important factor that determine the time of contact of dentifrices with the oral tissue. Hence in present study the time of brushing was standardized for about 2 minutes for all the participants. ${ }^{15}$

A study conducted by Abhinav Singh ${ }^{16}$ evaluated oral health knowledge, attitude and practice among NCC cadets and their correlation with oral hygiene in South India and stated that only $36.4 \%$ of subjects were aware for the use of dental floss as an interdental cleansing aid. In contrast, the present study only $2.5 \%$ knew about the use of dental floss as an interdental cleansing aid.

Childhood is an important life stage for establishing adulthood behaviors; during this age young people assume responsibility for learning and maintaining health related attitudes and behaviors. Hence the children can be educated about the caries preventive measures and motivated to use these dentifrices in their routine oral hygiene procedures. It appears to have the potential to make a major contribution towards education and motivation problem related to oral health

\section{Conclusion:}

- $\quad$ Knowledge regarding oral hygiene measures amongst 12 year school going children in Davangere was significantly low.

- Lecture method is an effective tool in increasing awareness and knowledge regarding oral hygiene and oral health in 12 year school going children.

- After 6 months, there was a significant reduction in memory gained after interventional program, dictates the need for regular reinforcement of educational and motivational programs.

\section{References}

1. Lisa H. Alsada , Michael J. Sigal , Hardy Limeback , James Fiege,GajananV. Kulkarni. Development and testing of an Audio-visual aid for improving infant oral health through primary caregiver education. J Can Edu, April 2005, vol.71, no.4. 71-74. 
2. Kay E, Locker D. A systemic review of the effectiveness of health promotion aimed at improving oral health. Comm Dent Health 1998: 15,132-144.

3. Chapman A, Copestake SJ, Duncan K. An oral health education program based on the national curriculum. Int J Pediatric Dent; 16: 40-44.

4. Tao He, Michael Britt, Aaron R. Biesbrock. Innovations in global dentifrice technology: An advanced stannous- containing sodium fluoride dentifrice. Am J Dent, 2010: 23: Sp Is B:3B-10B.

5. Cataldo W. Leone, Frank G. Oppenheim. Physical and chemical aspects of saliva as indicators of risk for dental caries in humans. $\mathrm{J}$ Dent Edu , Vol. 65, No. 10.

6. Flanders RA. Effectiveness of dental health education programs in schools. JADA 1987; 114: 239-242.

7. Albandar JM, Buischi YAP, Mayer MP A, Axelsson. Long term effect of two preventive programs on the incidence of plaque and gingivitis in adolescents. J Periodontal, 1994: 65: 605-610.

8. Mahmoud K.Al-Omari, Jor Board Ahed M. Al-Wahadni, Khaled N. Saeed. Oral health attitudes, knowledge, and behavior among school children in north Jordan. J Dent Edu.2006 ;14:50-53.

9. Ernesto Smyth, Francisco Caamaño, Paula Fernández-Riveiro. Oral health knowledge, attitudes and practice in 12-year-old schoolchildren. Med Oral Patol Oral Cir Bcal. 2007: 1;12(8):E614-20.

10. I.A. El Karim, N. M. Sanhouri, N. T.T Hashim. Dental erosion among 12-14 year old school children in Khartoum: a pilot study. Comm Dent health 2007: 24:176-180.

11. Poul Erik Peterson, NeilsHoerup, Nattaporn Poomviset, Janpim Prommajan and Achara Watanapa. Oral health status and oral health behavior of urban and rural school children in southern Thailand. Int Dent J 2001: 51; 95-102.

12. Kimberly Krust Bray. Tooth brushing behavior change. Am Dent Hyg Assoc. 2010 Sept-Oct.

13. Saxer UP, Barbakow J, Yankell SL. New studies on actual and estimated tooth brushing times and dentifrice use. J Clin Dent. 1998: 9:49-51.

14. Peng B, Petersen PE, Fan MW, Tai BJ. Oral health status and oral health behavior of 12-year-old urban school children in the people's republic of china. Comm Dent Health 1997:14: 238-244.

15. Gallagher A, Sowinski J, Bowman J et al. The effect of brushing time and dentifrice on dental plaque removal in vivo. J Dent Hyg. 2009; 83: 111-6.

16. A Singh. Oral Health Knowledge, Attitude and Practice among NCC Navy Cadets and their Correlation with Oral Hygiene in South India. Oral Health Prev Dent 7 2009, No. 4.

\section{How to cite this article:}

Poornima P. , Arora S, Neena IE, Shashibhushan KK, Nagaveni NB. An Effectiveness of Oral Health Promotion Program on 12 Year old School Going Children of South Indian Children.

CODS J Dent 2015;7:55-59.

Source of support: Nil. Conflict of interest: None Declared. 